\title{
A new species of the Eigenmannia trilineata (Gymnotiformes: Sternopygidae) species group from the río Orinoco basin, Venezuela
}

\author{
Luiz A. W. Peixoto ${ }^{1}$ and Brandon T. Waltz ${ }^{2}$
}

\begin{abstract}
A new species of the Eigenmannia trilineata species group is described from the río Orinoco basin, Venezuela. The new species is distinguished from congeners by a unique set of characters including an ossified basibranchial 1; 198-217 anal-fin rays; suborbital depth, $21.3-26.1 \% \mathrm{HL}$; length of anterodorsal process of maxilla equal to the width of the posterior nostril; premaxilla with 17 teeth distributed in three rows; hyaline pectoral and anal fins; and number of scale series above lateral line, 9-10. It raises the number of species allocated to the Eigenmannia trilineata species group to 13 and the number of species within the genus to 18 .
\end{abstract}

Keywords: Biodiversity, Electric-fishes, Taxonomy, Tuvira.

Se describe una nueva especie del grupo Eigenmannia trilineata de la cuenca del río Orinoco, Venezuela. La nueva especie se distingue de sus congéneres por una combinación única de caracteres, incluyendo el basibranquial 1 osificado; número de radios de la anal, 198-217; profundidad del suborbital, 21.3-26.1\% HL; longitud del proceso anterodorsal de la maxila igual al ancho de la narina posterior; 17 dientes premaxilares distribuidos en tres hileras; aletas pectoral y anal hialinas; y 9-10 hileras de escamas sobre la serie de la línea lateral. La presente contribución eleva el número de especies del grupo Eigenmannia trilineata a 13, y a 18 aquellas dentro del género.

Palabras Clave: Biodiversidad, Pez cuchillo, Peces eléctricos, Taxonomía.

\section{Introduction}

Commonly known as electric glass knifefishes or ituí transparente, Eigenmannia Jordan \& Evermann, 1896 is a genus of weakly electric freshwater fishes broadly distributed throughout most of the Neotropics on both sides of the Andes, from Panama to northern Argentina (Albert, 2001, 2003). Species within the genus exhibit a wavetype electric organ discharge and can be found in diverse habitats, from small streams and tributaries to floodplain lakes and large river channels (Crampton, Albert, 2006).

Following a series of contributions (Eigenmann, 1893; Jordan, Evermann, 1896; Ellis, 1913; Mago-Leccia, 1994; Triques, 1996; Albert, 2001; Peixoto et al., 2015; Peixoto, Wosiacki, 2016; Campos-da-Paz, Queiroz, 2017), seventeen species are currently recognized as valid in the genus Eigenmannia: E. antonioi Peixoto, Dutra \& Wosiacki, 2015 from the rio Anapu, rio Amazonas basin; E. besouro Peixoto \& Wosiacki, 2016 from tributaries in the rio São Francisco basin; E. correntes Campos-da-Paz \& Queiroz, 2017 from the rio Correntes, rio Paraguay basin; E. desantanai Peixoto, Dutra \& Wosiacki, 2015 from the rio Cuiabá, rio Paraguay basin; E. guairaca Peixoto, Dutra \& Wosiacki, 2015 from the riacho Água do Ò, upper rio Paraná basin; E. humboldtii (Steindachner, 1878) from the río Magdalena; E. limbata (Schreiner \& Miranda Ribeiro, 1903) from the Amazonas basin; E. macrops (Boulenger, 1897) from the Amazonas, Orinoco, and Guyanas basins; E. matintapereira Peixoto, Dutra \& Wosiacki, 2015 from the rio Uneiuxi and rio Urubaxi, rio Negro basin; E. microstoma (Reinhardt, 1852) from the rio São Francisco basin; E. muirapinima Peixoto, Dutra \& Wosiacki, 2015 from small tributaries of the Amazon River; E. nigra Mago-Leccia, 1994 from the rio Negro, río Orínoco, and rio Amazonas basins; E. pavulagem Peixoto, Dutra \& Wosiacki, 2015 from tributaries of the rio Capim, rio Guamá basin; E. trilineata López \& Castello, 1966 from the río de La Plata and rio Paraná; E. vicentespelaea Triques, 1996 from the São Vicente I and II caves, rio Tocantins basin; E. virescens (Valenciennes, 1836) from the rio Paraná; and E. waiwai Peixoto, Dutra \& Wosiacki, 2015 from the rio Trombetas basin.

${ }^{1}$ Setor de Ictiologia, Museu de Zoologia da Universidade de São Paulo, Av. Nazaré, 481, Ipiranga, 04299-970 São Paulo, SP, Brazil. luizwp@yahoo.com.br (corresponding author)

${ }^{2}$ Department of Biology, University of Louisiana at Lafayette, 410 E. St. Mary Blvd., LA, 70504-2451 Lafayette, USA. btwaltz09@gmail.com 
Albert (2001) proposed two species groups within Eigenmannia: the E. microstoma species group (consisting of E. humboldtii, E. microstoma, E. nigra, and E. limbata), with members possessing a deeper adult body size $(>11 \%$ $\mathrm{TL}$ ), and the $E$. virescens species group (consisting of $E$. virescens, E. trilineata, and an undescribed species), with members possessing two to three longitudinal stripes and highly branched anterior intermuscular bones. Recently, Peixoto et al. (2015) proposed a new classification for the longitudinally striped species, erecting the Eigenmannia trilineata species group, consisting of $E$. antonioi, $E$. desantanai, E. guairaca, E. matintapereira, E. microstoma, E. muirapinima, E. pavulagem, E. trilineata, $E$. vicentespelaea, and $E$. waiwai (thus removing E. microstoma from the E. microstoma species group and E. trilineata from the $E$. virescens species group). Most recently, two species were described for the group, E. besouro and E. correntes (Peixoto, Wosiacki, 2016; Campos-da-Paz, Queiroz, 2017). All current members of the Eigenmannia trilineata species group are found in the Amazon, Paraguay, Paraná, La Plata, and São Francisco drainages.

Based on analysis of material collected in the río Orinoco basin, we describe a new species of Eigenmannia belonging to the E. trilineata species group.

\section{Material and Methods}

Morphometric, meristic, and osteological nomenclature follow Lundberg, Mago-Leccia (1986) and Peixoto et al. (2015). Measurements were taken point-to-point to the nearest $0.1 \mathrm{~mm}$ using digital calipers under a stereomicroscope, preferentially utilizing the left side of each specimen. Abbreviations reported in this manuscript are total length (TL), the distance from the tip of the snout to distal margin of the caudal filament; length to end of anal fin (LEA), from the tip of the snout to the insertion of the last anal-fin ray; and head length (HL), from the tip of the snout to the posterior-most margin of the branchial opening. In the description, the frequencies of each count are expressed in parentheses and holotype data are indicated by an asterisk. In the pectoral and anal-fin ray counts, unbranched rays are represented by lower case Roman numerals and branched rays are indicated by Arabic numerals. Specimens were cleared and stained (c\&s) following the protocol of Taylor, Van Dyke (1985). Pre-caudal vertebrae counts include the four vertebrae of the Weberian apparatus. Herein, the "lateral line stripe" refers to the dark stripe along the lateral line; the "superior midlateral stripe" refers to the concentration of small separate chromatophores with diffuse margins located below the lateral line; the "inferior midlateral stripe" refers to the dark stripe located over the proximal portion of analfin pterygiophores; and the "anal-fin base stripe" refers to the dark stripe located on the base of the anal fin (Peixoto et al., 2015; Peixoto, Wosiacki, 2016). Morphological data of E. correntes were based on Campos-da-Paz, Queiroz (2017). Infraorbitals, premaxillary, dentary, and maxillary bones were cleared of soft tissue for scanning electron micrograph imaging by immersion in a $1 \%$ sodium hypochlorite solution for less than five minutes followed by air drying. Museum acronyms follow the guidelines of Sabaj (2016). Some specimens were excluded from the type series due to poor preservation status. No type-material was deposited in the country of origin of the new species due to a series of unsuccessful efforts.

\section{Results}

\section{Eigenmannia sayona, new species}

urn:1sid:zoobank.org:act:F127F01B-AC21-4D1B-BC4FEBAB9EA64854

\section{Fig. 1}

Holotype. MZUSP 96497, $131.8 \mathrm{~mm}$ LEA, Venezuela, Bolivar, Cedeño, río Parguaza, río Orinoco basin, near the community of Puente Parhueña, $5^{\circ} 53^{\prime} 30^{\prime \prime} \mathrm{N} 67^{\circ} 24^{\prime} 14^{\prime \prime} \mathrm{W}$, 19 Jul 2004, M. de Pinna \& C. Oliveira.

Paratypes. All from Venezuela. Bolivar: FMNH 130239, 1, 95.4 mm LEA; MPEG 33926, 1, 103.7 mm LEA; MZUSP 119711, $6+2$ c\&s, 27.8-116.2 mm LEA, collected with the holotype. MZUSP 96465, 1, $116.2 \mathrm{~mm}$ LEA, Caicara del Orinoco, río Orinoco, Laguna de Castilleros, $7^{\circ} 30^{\prime} 51^{\prime} \mathrm{N}$ 6609’20’W, 22 Jul 2004, M. de Pinna \& C. Oliveira.

Non-types. All listed specimens were directly preserved in alcohol (except USNM specimens). Venezuela. Apure: USNM 260225, 13, 47.1-68.5 mm LEA, Caño Caicara. Bolivar: LBP 2225, 1, 54.7 mm LEA, Caicara del Orinoco, río Orinoco, Laguna de Castilleros. LBP 2311, 3, 91.1-107.5 mm LEA, Cedeño, río Orinoco, río Parguaza. LBP 3083, 4, 53.6-65.1 mm LEA, Caicara del Orinoco, río Orinoco. LBP 9976, 3, 57.7-89.9 mm LEA (two specimens measured; one specimen damaged), Caicara del Orinoco, río Orinoco, Laguna de Castilleros.

Diagnosis. Eigenmannia sayona can be distinguished from its congeners, except species of the E. trilineata species group, by the presence of a superior midlateral stripe (vs. absence). Eigenmannia sayona can be differentiated from congeners in the E. trilineata species group by the ossification of the first basibranchial (Fig. 2) (vs. unossified). The new species can be distinguished from congeners in the $E$. trilineata species group, except $E$. correntes, by the unique dentition pattern of the premaxilla, 17 teeth distributed in three irregular rows (Fig. 3) (vs. eight to 12 teeth distributed in two rows in E. antonioi; 18-29 teeth distributed in three or four rows in E. besouro; 24 or 25 teeth distributed in four rows in E. desantanai; nine or ten teeth distributed in two rows in E. guairaca; 22-24 teeth distributed in four rows in E. matintapereira; 16 teeth distributed in three rows in 


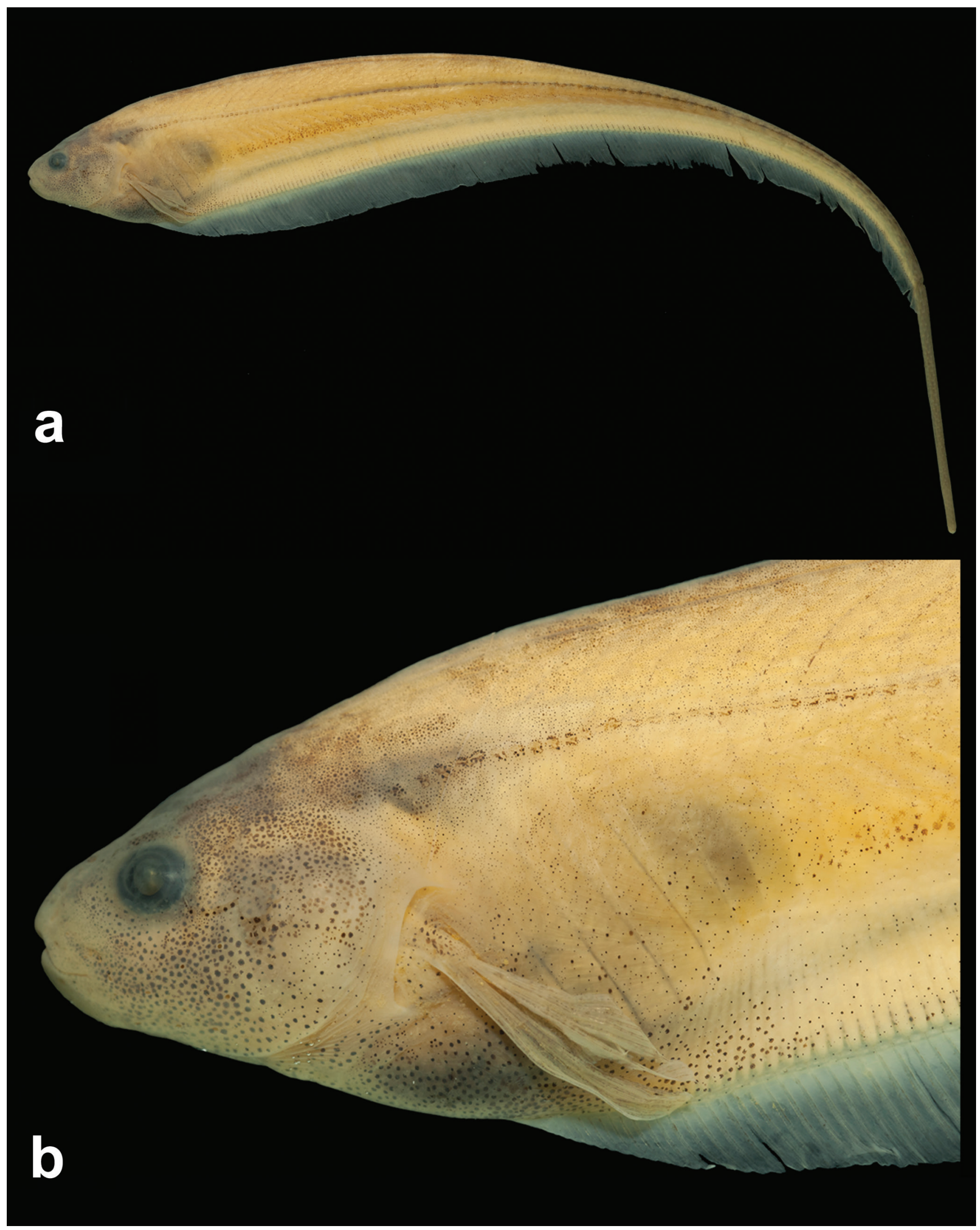

Fig. 1. Holotype of Eigenmannia sayona, new species, MZUSP 96497, 131.8 mm LEA, Venezuela, Bolivar, Cedeño, río Orinoco, río Parguaza, near the community of Puente Parhueña. a. Lateral view of head and body; b. Lateral view of head. 
E. microstoma; eight to ten teeth distributed in two rows in E. muirapinima; 13-16 teeth distributed in three rows in E. pavulagem; 31-33 teeth distributed in four rows in E. trilineata; 25 or 26 teeth distributed in four rows in $E$. vicestespelaea; 35 or 40 teeth distributed in five rows in E. waiwai). The new species can be differentiated from E. besouro, E. correntes, E. desantanai, E. guairaca, E. matintapereira, E. microstoma, E. trilineata, E. vicentespelaea, and $E$. waiwai by the dentition pattern of the dentary, with teeth increasing abruptly in size from the sixth or seventh tooth (Fig. 4) (vs. dentary teeth similar in size). Eigenmannia sayona can be further distinguished from other species in the E. trilineata species group, except $E$. antonioi, E. matintapereira, E. microstoma, E. muirapinima, E. pavulagem, and $E$. trilineata, by the number of anal-fin rays, 198-217 (vs. 150-181 in E. besouro; 143-164 in E. correntes; 170-196 in E. desantanai; 151-170 in E. guairaca; 169191 in E. vicentespelaea; $167-195$ in E. waiwai). The new species can be distinguished from $E$. besouro, $E$. desantanai, E. muirapinima, E. vicentespelaea, and $E$. waiwai by the number of tooth rows on the endopterygoid, 1 (vs. 2). The new species can be differentiated from E. besouro, E. correntes, E. desantanai, E. guairaca, E. microstoma, and $E$. trilineata by the number of precaudal vertebrae, 13 (vs. 14; 14; 11-12; 15; 14-15; and 14, respectively). Eigenmannia sayona can be differentiated from E. antonioi, E. correntes, E. desantanai, E. guairaca, E. muirapinima, $E$. pavulagem, E. vicentespelaea, and $E$. waiwai by the length of the anterodorsal process of maxilla being equal to the width of the posterior nostril (Fig. 5) (vs. equal to 1.5 times the width of the posterior nostril in E. waiwai; or approximately $20-50 \%$ of the width of the posterior nostril in aforementioned species - Fig. 4b of Peixoto et al., 2015). Eigenmannia sayona can be further differentiated from $E$. besouro, E. correntes, E. matintapereira, E. trilineata, and $E$. waiwai by the depth of the posterodorsal expansion on infraorbitals $1+2$, approximately equal to the total length of infraorbitals $1+2$ (Fig. 6 ) ( $v$ s. less than $50 \%$ of the length of infraorbitals $1+2$ ). The new species differs from $E$. besouro, E. correntes, E. vicentespelaea and E. waiwai by possessing a terminal mouth (vs. subterminal). The new species can be distinguished from E. microstoma and E. trilineata by the suborbital depth, 20.6-26.8\% HL (vs. 29.9-40.8\%; and $32.5-46.6 \%$, respectively). Eigenmannia sayona can be distinguished from E. microstoma and E. vicentespelaea by the number of scales above lateral line, 9-10 (vs. 11-15; and 7-8, respectively). Eigenmannia sayona can be differentiated from E. matintapereira, E. trilineata, and E. vicentespelaea by the number of pectoral-fin rays, ii,12-13 (vs. ii,16-17; ii,1415; and ii,15-17, respectively). Eigenmannia sayona can be differentiated from E. matintapereira, E. muirapinima, and E. waiwai, by oral width, 18.7-21.7\% HL (vs.12.6-16.1\%; 13.2-18.1\%; and 9.5-14.6\%, respectively). Eigenmannia sayona can be further distinguished from E. guairaca and $E$. waiwai by orbital diameter, 17.3-22.4\% HL (vs. 11.4-15.0\%; and 22.6-28.8\%, respectively). Eigenmannia sayona differs from E. guairaca by postorbital distance, $50.1-55.5 \% \mathrm{HL}$ (vs. 56.8-61.9\%). Eigenmannia sayona can be distinguished from E. matintapereira by the pectoral-fin coloration hyaline (vs. uniformly dark or with a median blotch); by the anal-fin distal margin coloration hyaline (vs. uniformly darkened); and by the posterior nostril to orbit distance, $6.9-9.9 \% \mathrm{HL}$ (vs. 2.5-6.6\%). The new species can be further distinguished from E. vicentespelaea by the snout length, $22.5-28.3 \% \mathrm{HL}$ (vs. 28.6-36.8\%).

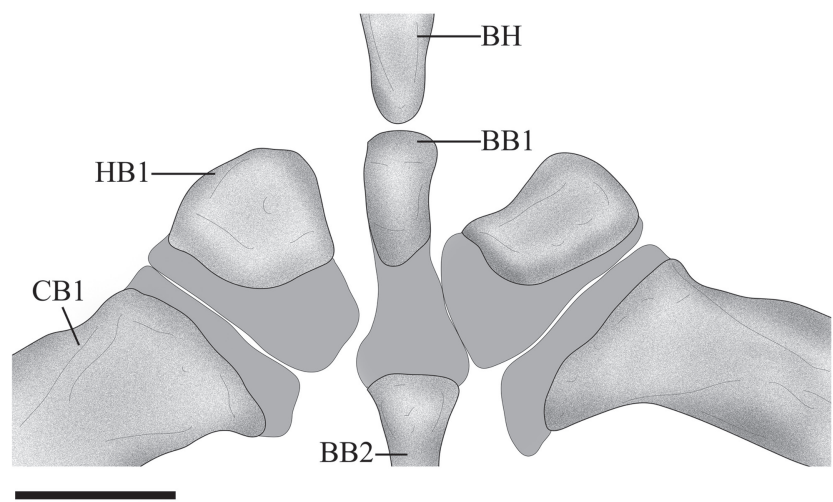

Fig. 2. Dorsal view of anterior portion of gill arches of Eigenmannia sayona (MZUSP 119711, paratype, $90 \mathrm{~mm}$ LEA). $\mathrm{BH}=$ basihyal; $\mathrm{BB} 1=$ basibranchial 1 ; $\mathrm{BB} 2=$ basibranchial $2 ; \mathrm{HB} 1=$ hypobranchial $1 ; \mathrm{CB} 1=$ ceratobranchial 1. Cartilage represented by gray coloration. Scale bar: $0.5 \mathrm{~mm}$.

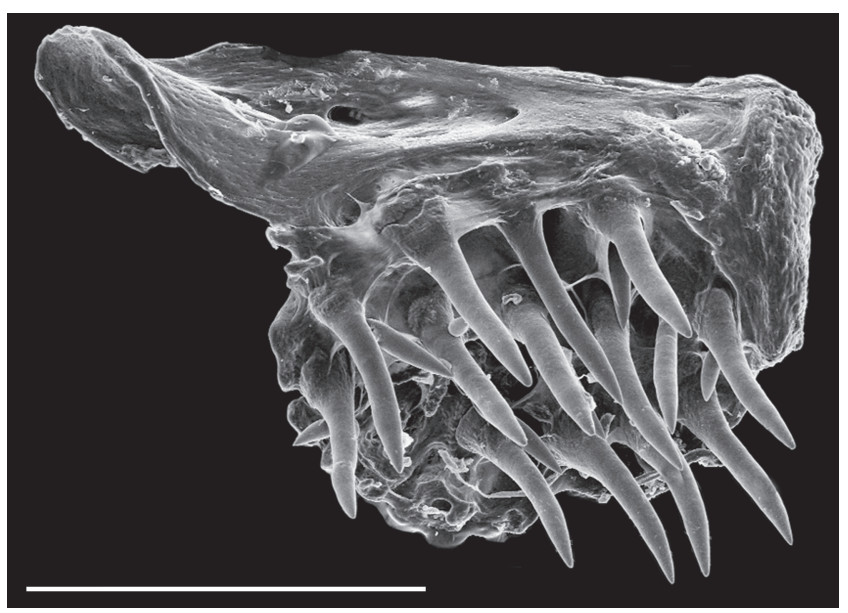

Fig. 3. Scanning electron micrograph. Ventral view of left premaxilla, showing the dentition pattern of Eigenmannia sayona (MZUSP 119711, paratype, 116.2 mm LEA). Scale bar: $0.5 \mathrm{~mm}$.

Description. Species of small/medium size, maximum length recorded $131.8 \mathrm{~mm}$ TL. Morphometric data is presented in Tab. 1. Body elongate and laterally compressed. Dorsal profile of body nearly straight or slightly convex from posterior margin of head to vertical line through middle of anal fin, and then posterodorsally angled in a straight line to distal portion of caudal filament. Ventral profile of body 
slightly concave along anterior half of abdominal cavity; then posteriorly angled to last anal-fin ray. Ventral profile of caudal filament straight. Greatest body depth at vertical line through distal margin of pectoral fin. Head laterally compressed, greatest width at posterior opercular region and greatest depth at posterior margin of supraoccipital. Dorsal profile of head slightly convex or nearly straight from upper lip to vertical through branchial opening. Ventral profile of head slightly concave from anterior margin of lower lip to branchial opening. Snout rounded in profile. Mouth terminal. Upper lip slightly overlapping lower lip or lips equal in length. Premaxilla teeth 17(2) in three rows [outermost row with 4(2) teeth; median row with 6(2); innermost row with 7(2) teeth, Fig. 3]. Maxilla with sickleshaped anterodorsal process equal to the width of posterior nostril. Dentary teeth 19(1) or 26(1) in two irregular rows [outermost row with 11(1) or 14(1); innermost row teeth, $8(1)$ or 12(1), Fig. 4]. Dentary teeth increasing abruptly in size from the sixth or seventh tooth of outermost row towards rictus. Coronomeckelian bone equal to $30 \%$ of length of Meckel's cartilage. Endopterygoid teeth 8(1) or 9(1) in a single row. Mouth rictus at vertical line through anterior nostril or in region between nostrils. Anterior nares tubular, posterior margin at vertical line through posterior margin or middle portion of rictus. Posterior nares elliptical, non-tubular, and closer to anterior margin of eye than tip of snout. Eye approximately circular, covered by skin, lateral on anterior half of head. Antorbital and infraorbitals 1-4 enlarged partial cylinders with slender osseous arches. Fifth and sixth infraorbitals slender and tubular. Depth of posterodorsal expansion on infraorbitals $1+2$ equal to total length of infraorbitals 1+2 (Fig. 5). Branchial opening moderately elongate. Branchial membrane joined with isthmus. Anus and urogenital papilla shifting anteriorly during ontogeny, from vertical line through posterior portion of opercle in juveniles [minimum examined $47.1 \mathrm{~mm}$ LEA] to vertical line through posterior portion of eye in adults. Anus and urogenital papilla at vertical line through posterior margin of eye in mature specimens.

Cycloid scales present from posterior margin of head to distal portion of caudal filament. Lateral line complete, 122(2), 124(1), 125(2), 127(2), 128*(1), 132(1), 134(2) or 136(1) perforated scales to vertical line through end of anal fin $(\mathrm{N}=12)$. Longitudinal series of scales above lateral line at distal margin of pectoral fin, $9 *(5), 10(7)$ or 11(4). Scales over anal-fin pterygiophores approximately one-half size of others.

Pectoral-fin rays, ii,12*(6) or ii,13(11); distal margin slightly rounded; tip reaching vertical through $16^{\text {th }}$ to $27^{\text {th }}$ anal-fin ray. Anal-fin origin posterior to vertical line through pectoral-fin base; total anal-fin rays, 198*-217 (N=14); distal margin of anal fin slightly convex. Caudal filament cylindrical, tapering gradually distally, relatively short and approximately $40 \%$ of LEA in mature specimens.

Precaudal vertebrae 13(2). Anterior vertebrae 10(1) or 12(1), transitional vertebrae 1(1) or 3(1). Displaced hemal spines 3(2).

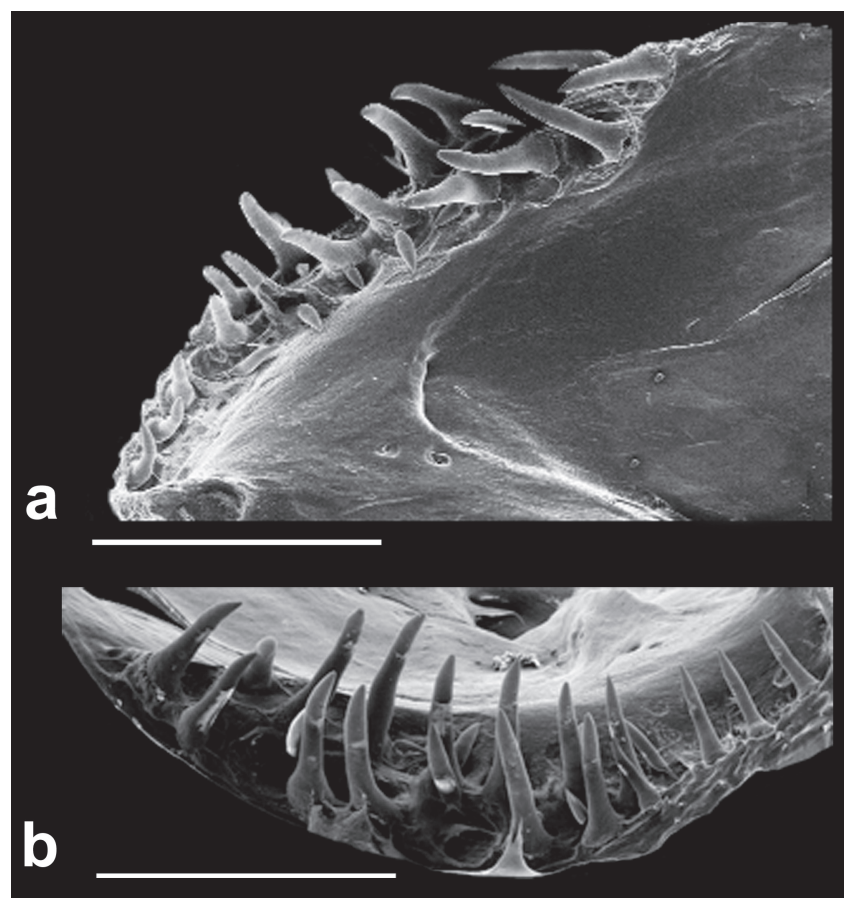

Fig. 4. Scanning electron micrographs. (a) lateral view and (b) dorsal view of right dentary of Eigenmannia sayona (MZUSP 119711, paratype, $116.2 \mathrm{~mm}$ LEA), showing the dentition pattern. Scale bar: $1 \mathrm{~mm}$.

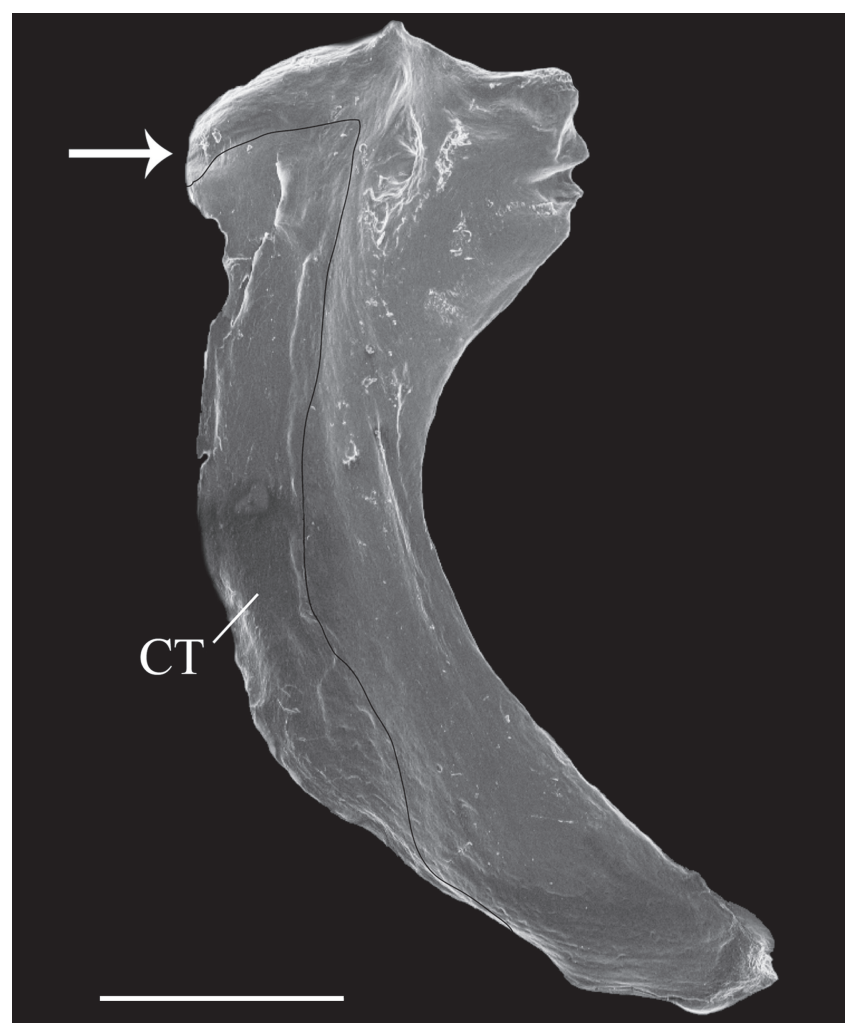

Fig. 5. Scanning electron micrograph of left maxilla (inverted) of Eigenmannia sayona in lateral view, anterior to left (MZUSP 119711, paratype, $116.2 \mathrm{~mm} \mathrm{LEA).} \mathrm{CT=}$ connective tissue on leading edge of maxilla. Arrow indicates the anterodorsal process. Scale bar: $0.5 \mathrm{~mm}$. 


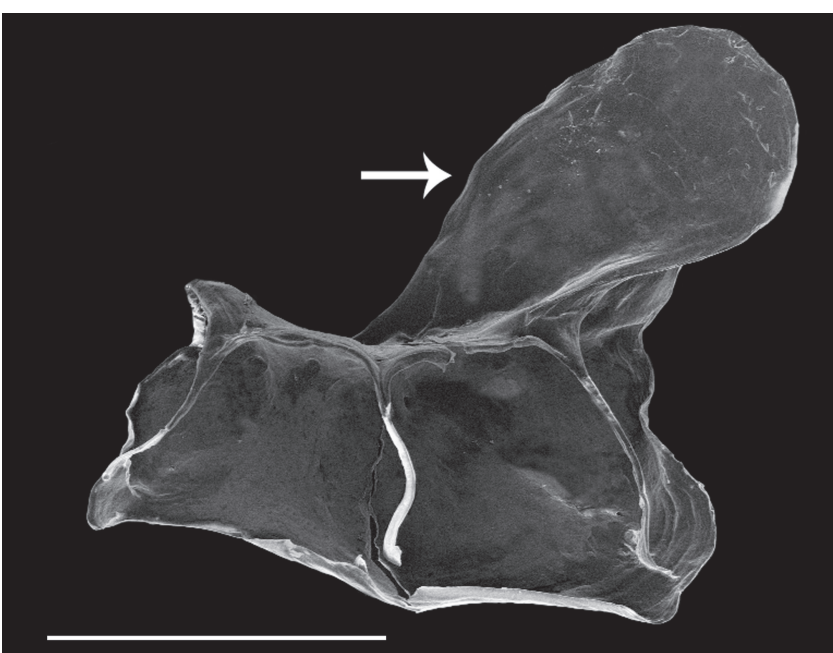

Fig. 6. Scanning electron micrograph of right infraorbital $1+2$ of Eigenmannia sayona in lateral view, anterior to right (MZUSP 119711, paratype, $116.2 \mathrm{~mm}$ LEA). Arrow indicates the posterodorsal expansion. Scale bar: $1 \mathrm{~mm}$.

Tab. 1. Morphometric data for Eigenmannia sayona, new species. Min $=$ minimum; $\mathrm{Max}=$ maximum; $\mathrm{SD}=$ standard deviation; $\mathrm{N}=$ number of specimens measured.

\begin{tabular}{lcccccc}
\hline & Holotype & Min & Max & Mean & SD & N \\
\hline Total length (mm) & 160.0 & 113.8 & 160.0 & - & - & 13 \\
Length to end of anal fin (mm) & 131.8 & 65.3 & 131.8 & - & - & 14 \\
Head length (mm) & 13.6 & 9.2 & 15.8 & - & - & 14 \\
& \multicolumn{5}{c}{ Percentage of LEA } \\
Head length & 10.3 & 10.3 & 15.1 & 12.3 & 1.7 & 14 \\
Preanal distance & 13.5 & 12.7 & 18.9 & 15.2 & 1.9 & 14 \\
Prepectoral distance & 11.3 & 11.3 & 16.3 & 13.1 & 1.8 & 14 \\
Snout to anus & 5.6 & 5.6 & 8.0 & 6.8 & 0.9 & 14 \\
Body depth at pectoral fin & 13.3 & 12.9 & 18.8 & 15.6 & 2.1 & 14 \\
Body depth at anal fin & 12.1 & 11.7 & 16.0 & 13.9 & 1.5 & 14 \\
Body width & 4.2 & 4.1 & 6.1 & 4.9 & 0.8 & 14 \\
Anal-fin length & 89.6 & 80.0 & 89.6 & 85.4 & 2.1 & 14 \\
Pectoral-fin length & 7.7 & 7.3 & 11.2 & 8.6 & 1.5 & 13 \\
Caudal-filament length & 22.6 & 21.2 & 44.5 & 34.8 & 7.9 & 11 \\
Caudal-filament depth & 1.6 & 1.2 & 2.6 & 1.4 & 0.1 & 11 \\
Caudal-filament width & 1.0 & 0.7 & 1.1 & 0.9 & 0.1 & 11 \\
& & Percentage of HL & & \\
Snout length & 25.1 & 22.5 & 28.3 & 25.3 & 1.8 & 16 \\
Internasal distance & 9.5 & 7.2 & 10.5 & 9.0 & 1.1 & 16 \\
Snout to posterior naris distance & 19.8 & 16.3 & 21.0 & 19.0 & 1.6 & 16 \\
Posterior naris to orbit distance & 7.3 & 6.9 & 9.9 & 8.1 & 1.1 & 16 \\
Internarial width & 17.3 & 14.6 & 18.4 & 16.8 & 1.1 & 16 \\
Orbital diameter & 20.6 & 17.3 & 22.4 & 20.1 & 1.2 & 16 \\
Postorbital distance & 52.3 & 50.1 & 55.5 & 52.4 & 1.9 & 16 \\
Opercular opening & 25.9 & 23.9 & 32.1 & 28.2 & 1.9 & 16 \\
Suborbital depth & 21.3 & 20.6 & 26.8 & 23.2 & 2.1 & 16 \\
Interorbital distance & 34.0 & 27.9 & 37.2 & 33.2 & 1.9 & 16 \\
Head width at opercle & 63.3 & 58.3 & 66.1 & 61.4 & 2.6 & 16 \\
Head width at orbits & 50.9 & 39.5 & 50.9 & 46.3 & 2.9 & 16 \\
Head depth at supraoccipital & 77.9 & 74.2 & 82.3 & 79.1 & 2.3 & 16 \\
Head depth at orbits & 58.4 & 53.9 & 64.2 & 58.5 & 3.1 & 16 \\
Maxilla length & 23.2 & 15.9 & 23.2 & 19.4 & 2.5 & 16 \\
Oral width & 20.1 & 18.7 & 21.7 & 20.0 & 1.1 & 16 \\
\hline & & & & &
\end{tabular}

Coloration in alcohol. Background color dark yellow. Dorsal region of head dark yellow; gradually lighter ventrally with sparse chromatophores in ventral portion. Lips and suborbital region light brown. Dorsal region of body dark brown, gradually lighter ventrally towards region overlying anal-fin pterygiophores. Four dark longitudinal stripes along body. Lateral-line stripe thin, one or two scales deep, extending from first perforated lateral-line scale to distal portion of caudal filament. Superior midlateral stripe thick, two scales deep, tapering approximately from vertical line between base of $20^{\text {th }}$ to $28^{\text {th }}$ anal-fin ray to posterior second-third of body in specimens. Inferior midlateral stripe moderately thick, two or three scales deep, extending from vertical line approximately between base of $25^{\text {th }}$ to $30^{\mathrm{h}}$ anal-fin ray to posterior-most one-third of body. Anal-fin base stripe thick, two scales deep, extending from vertical between base of first anal-fin ray to last anal-fin ray. Pectoral and anal fins hyaline, scattered tiny chromatophores on interradial membranes.

Geographic distribution. Eigenmannia sayona is known from río Orinoco basin, from río Parguaza, río Apure, and Laguna de Castilleros, Venezuela (Fig. 7).

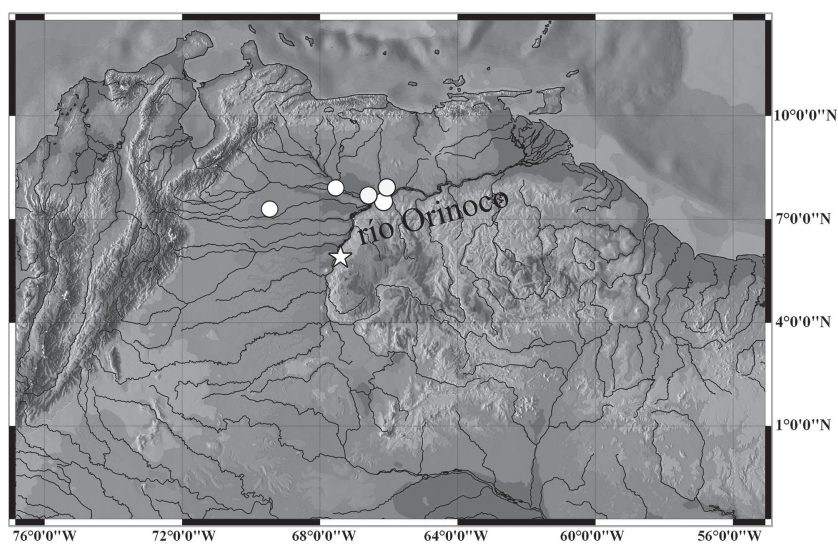

Fig. 7. Map of northern South America, illustrating the geographic distribution of Eigenmannia sayona. Star indicates type locality. Some points represent more than one locality.

Etymology. The specific epithet "sayona" is assigned to the new species in reference to "La Sayona", a spirit of philanderous vengeance in Venezuelan lore. A noun in apposition.

\section{Discussion}

Currently, Eigenmannia lacks diagnostic characters common to all species within the genus (Mago-Leccia, 1994; Albert, 2001), resulting in confusion regarding the generic limits within Sternopygidae. Thus, we opt to identify E. sayona as a member of Eigenmannia by its possession of all synapomorphies common to the Eigenmanniinae (Albert, 2001), and the absence of most characters diagnostic to other genera of Sternopygidae. 
Correa et al. (2006) proposed six synapomorphies for Rhabdolichops, none of which are present in E. sayona. Another eigenmanniin genus, Distocyclus, was recently distinguished from other genera in the subfamily by four autapomorphies (see Dutra et al., 2014), of which E. sayona shares none. Vari et al. (2012) proposed four synapomorphies for Archolaemus, all of which are absent in E. sayona, except for the ventral surface of the upper lip porous, possibly representing a case of convergence (Vari et al., 2012 noted another possible convergence of upper lip surface morphology between Archolaemus and an undescribed species in the E. trilineata group). In the same study, Vari et al. (2012) proposed six synapomorphies for Japigny, all of which are absent in E. sayona. Therefore, E. sayona can be excluded from all other diagnosed genera in Eigenmaniinae and is assigned provisionally to the genus Eigenmannia.

Approximately 50 species of gymnotiforms inhabit the río Orinoco basin (Mago-Leccia, 1994; Campos-da-Paz, 1995; Albert, 2003; Campos-da-Paz, 2003; de Santana, Crampton, 2007, 2011; de Santana, Vari, 2009, 2010a, 2010b, 2012, 2014; Lundberg et al., 2013; Ivanyisky, Albert, 2014). Five species of Eigenmannia have been reported, among them: E. limbata, E. humboldtii, E. macrops, E.nigra, and E. virescens (e.g. Mago-Leccia, 1978; MagoLeccia, 1994; Albert, 2001, 2003; Lasso et al., 2004).

In the most complete taxonomic study of sternopygids from Venezuela, Mago-Leccia (1978) recorded the presence of E. virescens and E. macrops (aside from E. humboldtii, which may refer to E. limbata, and E. nigra), in the río Orinoco basin. However, the specific delimitations of $E$. macrops and E. virescens are historically controversial due to taxonomic confusion resulting from insufficient descriptions and inadequate diagnostic characters. The lack of type material and type-locality information regarding $E$. virescens has led us to restrict the application of this name only to populations without stripes from the La Plata and Paraná basin (see additional comments in Peixoto et al., 2015). Furthermore, Mago-Leccia (1978) mentions two or three longitudinal stripes associated with and near the lateral line in specimens identified by him as $E$. virescens; however, this information does not correspond to Valenciennes (1836; plate xiii), which includes a drawing of a specimen without longitudinal stripes on body surface. Thus, the identity of the specimens listed as E. virescens in Mago-Leccia (1978) remains uncertain.

Similarly, analyses performed on the holotype and topotypes of $E$. macrops raise concern regarding the identity of specimens listed as E. macrops from the data presented in Mago-Leccia (1978). Mago-Leccia (1978) described the presence of two or three stripes on the body surface of $E$. macrops; however, this character contradicts the original description by Boulenger (1897), which described the body surface of E. macrops as uniform pale brownish. Because of these conflicting descriptions, we opt to temporarily consider the material listed in Mago-Leccia (1978) to be two unnamed species of Eigenmannia. Unfortunately, the listed specimens could not be analyzed during this study due to difficulty in accessing the material. A study is currently in development to clarify the taxonomic uncertainty surrounding the identity of E. macrops and E. virescens.

Comparative material examined. Material examined in addition to that listed in Peixoto et al. (2015). Eigenmannia macrops: Guyana: BMNH 1897.8.6.1, holotype of Sternopygus macrops, 128.6 mm LEA. USNM 405266, 6 of 16, 65.7-163.9 mm LEA. Eigenmannia guairaca: Brazil: LBP 9911, 1 of 3, 104.9 mm LEA. Eigenmannia nigra: Brazil: MPEG 2430, 7+1c\&s, 154.0-262.5 mm. Eigenmannia limbata: Brazil: MZUSP 75569, 1 of 2, 231.2 mm LEA.

\section{Acknowledgments}

The authors ackowledge James Maclaine (BMNH); Leo Smith, Mary Rogers, Susan Mochel, and Caleb McMahan (FMNH); Claudia Uribe (IAvH); Lúcia Py-Daniel and Renildo de Oliveira (INPA); Gustavo Chiaramonte and Ricardo Ferriz (MACN); Zilda Lucena and Carlos Lucena (MCP); Marcelo Britto (MNRJ); José Figueredo, Naércio Menezes, Mário de Pinna, Osvaldo Oyakawa, Aléssio Datovo and Michel Gianeti (MZUSP); Carla Pavanelli (NUP); Richard Vari, Lynne Parenti, Jeff Clayton, and Sandra Raredon (USNM); Cláudio Oliveira (LBP); Wolmar Wosiacki and Izaura Guimarães (MPEG) for the loan of specimens and assistance during visits to their institutions. The authors also acknowledge Fernando Dagosta for assistance in preparation of the holotype figure and Gustavo Ballen for providing the "Resumen". The authors thank the Laboratório de Microscopia Eletrônica do Museu de Zoologia and Lara Guimarães (MZUSP) for the technical support during the preparation of scanning electron micrographs images. This manuscript has benefitted by helpful comments and suggestions from James Albert and Maxwell Bernt. BTW acknowledges his wife, Kassandra Waltz, for her patience and helpful comments throughout the development of the study. LAWP is supported by FAPESP (processes\# 2013/09926-3 and BEPE 2015/24709-4).

\section{References}

Albert JS. Species diversity and phylogenetic systematics of American knifefishes (Gymnotiformes, Teleostei). Ann Arbor: University of Michigan; 2001. (Museum of Zoology, University of Michigan. Miscellaneous Publications; No. 190).

Albert JS. Family Sternopygidae. In: Reis RE, Kullander SO, Ferraris CJ, Jr., organizers. Check list of the freshwater fishes of South and Central America. Porto Alegre: Edipucrs; 2003. p.487-491.

Boulenger GA. Description of a new gymnotine fish of the genus Sternopygus. Ann Mag Nat Hist. 1897; 6(20):305.

Campos-da-Paz R. Revision of the South American freshwater fish genus Sternarchorhamphus Eigenmann, 1905 (Ostariophysi: Gymnotiformes: Apteronotidae), with notes on its relationships. Proc Biol Soc Wash. 1995; 108(1):29-44. 
Campos-da-Paz R. Gymnotidae (Naked-back knifefishes). In: Reis RE, Kullander SO, Ferraris CJ, Jr., organizers. Check list of the freshwater fishes of South and Central America. Porto Alegre: Edipucrs; 2003. p.483-486.

Campos-da-Paz R, Queiroz IR. A new species of Eigenmannia Jordan and Evermann (Gymnotiformes: Sternopygidae) from the upper rio Paraguai basin. Zootaxa. 2017; 4216(1):73-84.

Correa SB, Crampton WGR, Albert JS. Three new species of the neotropical electric fish Rhabdolichops (Gymnotiformes: Sternopygidae) from the Central Amazon, with a new diagnosis of the genus. Copeia. 2006; 2006(1):27-42.

Crampton WGR, Albert JS. Evolution of electric signal diversity in gymnotiform fishes. In: Ladich F, Collin SP, Moller P, Kapoor BG, editors. Communication in fishes. Enfield: Science Publishers; 2006. p.647-731.

Dutra GM, de Santana CD, Vari RP, Wosiacki WB. The South american electric glass knifefish genus Distocyclus (Gymnotiformes: Sternopygidae): redefinition and revision. Copeia. 2014; 2014(2):345-54.

Eigenmann CH. V. - Notes on some South American fishes. Ann N Y Acad Sci. 1893; 7:625-37.

Ellis MM. The gymnotid eels of Tropical America. Mem. Carnegie Mus. 1913; 6(3): 109-95.

Ivanyisky III SJ, Albert JS. Systematics and biogeography of Sternarchellini (Gymnotiformes: Apteronotidae): diversification of electric fishes in large Amazonian rivers. Neotrop Ichthyol. 2014; 12(3):565-84.

Jordan DS, Evermann BW. The fishes of North and Middle America: a descriptive catalogue of the species of fish-like vertebrates found in the waters of North America, north of the isthmus of Panama. Bull U S Natl Mus. 1896; 47(1):1-1240.

Lasso CA, Mojica JI, Usma JS, Maldonado-O JA, DoNascimento C, Taphorn DC et al. Peces de la cuenca del río Orinoco. Parte I: lista de especies y distribución por subcuencas. Biota Colombiana. 2004; 5(1):95-158.

Lundberg JG, Mago-Leccia F. A review of Rhabdolichops (Gymnotiformes, Sternopygidae), a genus of South American freshwater fishes, with descriptions of four new species. Proc Acad Nat Sci Philadelphia. 1986; 138(1):53-85.

Lundberg JG, Cox-Fernandes C, Campos-da-Paz R, Sullivan JP. Sternarchella calhamazon n. sp., the Amazon's most abundant species of apteronotid electric fish, with a note on the taxonomic status of Sternarchella capanemae Steindachner, 1868 (Gymnotiformes, Apteronotidae). Proc Acad Nat Sci Philadelphia. 2013; 162:157-73.

Mago-Leccia F. Los peces de la familia Sternopygidae de Venezuela. Act Cient Venez. 1978; 29(1):1-91.

Mago-Leccia F. Electric fishes of the continental waters of America: classification and catalogue of the electric fishes of the order Gymnotiformes (Teleostei: Ostariophysi), with descriptions of new genera and species. Caracas: FUDECI; 1994. (Biblioteca de la Academia de Ciencias Físicas, Matemáticas y Naturales; vol 29).

Peixoto LAW, Dutra GM, Wosiacki WB. The electric glass knifefishes of the Eigenmannia trilineata species-group (Gymnotiformes: Sternopygidae): monophyly and description of seven new species. Zool J Linnean Soc. 2015; 175(2):384-414.
Peixoto LAW, Wosiacki WB. Eigenmannia besouro, a new species of the Eigenmannia trilineata species-group (Gymnotiformes: Sternopygidae) from the rio São Francisco basin, northeastern Brazil. Zootaxa. 2016; 4126(2):262-70.

Sabaj MH. American Society of Ichthyologists and Herpetologists. Standard symbolic codes for institutional resource collections in herpetology and ichthyology: an online reference. Version 6.5 [Internet]. 2016 [updated 2016 Aug 16]. Available from: http://www.asih.org/resources/standard-symbolic-codesinstitutional-resource-collections-herpetology-ichthyology

de Santana CD, Crampton WG. Revision of the deep-channel electric fish genus Sternarchogiton (Gymnotiformes: Apteronotidae). Copeia. 2007; 2007(2):387-402.

de Santana CD, Crampton WG. Phylogenetic interrelationships, taxonomy, and reductive evolution in the Neotropical electric fish genus Hypopygus (Teleostei, Ostariophysi, Gymnotiformes). Zool J Linnean Soc. 2011; 163(4):1096-156.

de Santana CD, Vari RP. The South American electric fish genus Platyurosternarchus (Gymnotiformes: Apteronotidae). Copeia. 2009; 2009(2):233-44.

de Santana CD, Vari RP. New rheophilic species of electric knifefish from the rapids and waterfalls of the lower rio Xingu, Brazil (Gymnotiformes, Apteronotidae). Copeia. 2010a; 2010(1):160-64.

de Santana CD, Vari RP. Eletric fishes of the genus Sternarchorhynchus (Teleostei, Ostariophysi, Gymnotiformes): phylogenetic and revisionary studies. Zool J Linnean Soc. 2010b; 159(1):223-371.

de Santana CD, Vari RP. New species of Adontosternarchus (Gymnotiformes, Apteronotidae) from the rio Purus basin, Brazil. Copeia. 2012; 2012(3):535-40.

de Santana CD, Vari RP. Brown ghost electric fishes of the Apteronotus leptorhynchus species-group (Ostariophysi, Gymnotiformes): monophyly, major clades, and revision. Zool J Linnean Soc. 2013; 168(3):564-96.

Taylor WR, Van Dyke GC. Revised procedures for staining and clearing small fishes and other vertebrates for bone and cartilage study. Cybium. 1985; 9(2):107-19.

Triques ML. Eigenmannia vicentespelaea, a new species of cave dwelling electrogenic neotropical fish (Ostariophysi: Gymnotiformes: Sternopygidae). Revue Fr Aquariol. 1996; 23(1-2):1-4.

Vari RP, de Santana CD, Wosiacki WB. South American electric knifefishes of the genus Archolaemus (Ostariophysi, Gymnotiformes): undetected diversity in a clade of reophiles. Zool J Linnean Soc. 2012; 165(3):670-99.

Valenciennes A. Poissons. In: d'Orbigny A, editor. Voyage dans l'Amérique Méridionale (le Brésil, la République Orientale de l'Uruguay, la République Argentine, la Patagonie, la République du Chili, la République de Bolivia, la République du Pérou), exécuté pendant les années 1826, 1827, 1828, 1829, 1830, 1832 et 1833. Paris: Bertrand et Levrault; 1836. p.1-11.

Submitted January 14, 2016 Accepted January 25, 2017 by George Mattox 